\title{
Comparative anatomy and physiology of myrmecophytes: ecological and evolutionary perspectives
}

This article was published in the following Dove Press journal:

Research and Reports in Biodiversity Studies

I October 2015

Number of times this article has been viewed

\author{
Marcia González-Teuber ${ }^{1}$ \\ Martin Heil ${ }^{2}$ \\ 'Department of Biology, Universidad \\ de La Serena, La Serena, Chile; \\ ${ }^{2}$ Department of Genetic Engineering, \\ CINVESTAV, Irapuato, Guanajuato, \\ México
}

\begin{abstract}
Ant-plant interactions are classic examples of defensive mutualisms and have served as model systems to study the ecology and evolution of mutualisms since the 19th century. Ant-plant mutualisms range in specificity from myrmecophilic (ant-loving) plants, which attract free-living ants to obtain defense against herbivores, to obligate myrmecophytes (antsplants), which provide specialized structures such as shelter and, in most cases, food rewards such as extrafloral nectar (EFN) and food bodies (FBs) to specialized ants. These ants usually cannot be found nesting outside of these plants. Myrmecophytic plants house and nourish ant colonies to establish obligate, long-term interactions. In return for food and shelter, the symbiotic ants mainly defend their host against herbivores and pathogens; in some cases, they supply nutrients. Here, we will review the anatomical and physiological features of the rewards that myrmecophytes provide to ants: EFN, FBs, and domatia (shelter). The anatomical and chemical features of these rewards match their physiological and ecological functions to attract, feed, and house ants. Recent studies in several systems demonstrated how the chemical composition of these rewards and spatiotemporal patterns in their production ensure their optimized exchange among specialized mutualistic partners and reduce the exploitation risk by nonreciprocating species. However, it remains to be studied how the production of rewards is regulated by the plant and whether it represents a specific plant response to the presence and identity, or rather the concrete actions, of the symbiotic ant partner. More research is needed, particularly with respect to the production and formation of domatia, which have been far less studied than EFNs and FBs. In obligate defensive mutualisms, a feedback between host plants and resident ants, in terms of the benefits they provide each other, it is likely to occur.
\end{abstract}

Keywords: ant-plant mutualisms, extrafloral nectar, food bodies, domatia, mutualistic ants

\section{Introduction}

Interactions between ants and plants are taxonomically and ecologically widespread and represent some of the most-studied examples of mutualisms: interactions among different species in which the fitness of each participant is enhanced by the presence or action of its partner. ${ }^{1}$ The coevolution between ants and plants, which has led to the emergence of these multiple systems of defensive ant-plant mutualisms, involves a system of services and rewards, resulting in a high taxonomic and functional diversity of complex interactions. ${ }^{2}$ Defensive ant-plant mutualisms can range from facultative, nonspecific relationships to obligate, highly specific symbiotic mutualisms without which neither of the involved partners can achieve positive fitness. ${ }^{2}$ Given that many genera of ants and plants comprise species that engage in either obligate or facultative interactions, these interactions have frequently served as models to study
Correspondence: Marcia González-Teuber Department of Biology, Universidad de La Serena, Casilla 554, La Serena 1700000 , Chile Tel +565I 2334637

Emailmfgonzalez@userena.cl 
the evolutionary stability of mutualisms, ${ }^{3-7}$ plant defense strategies, ${ }^{8,9}$ species coexistence, ${ }^{5,10-12}$ and multitrophic interactions. ${ }^{13}$ For the purpose of this review, we have used the term "myrmecophyte" (ant-plant) for plants that establish obligate, symbiotic interactions with specific ants, usually via the provisioning of space for housing in so-called domatia. ${ }^{14-16}$ Plants that attract ants via the provisioning of food rewards but do not engage in specific, symbiotic interactions with ants are termed "myrmecophilic" (ant-loving).

In general, plants provide housing and/or food rewards to ants (Table 1 and Figure 1), while ants act mainly as an indirect defense against herbivores. Facultative interactions are usually based on the attraction of generalist ants to food rewards such as extrafloral nectar (EFN) and food bodies (FBs). Obligate defensive ant-plant mutualisms are mainly restricted to the tropics, involve species in over 100 genera of angiosperms and 40 genera of ants, ${ }^{16}$ and always based on the provisioning of nesting space (domatia) by the plant, which can be accompanied by additional food rewards (EFN and/ or FBs). Domatia lead to more stable and specific associations, because they allow myrmecophytes to host an entire ant colony for a prolonged time span. In consequence, myrmecophytes are commonly assumed to be more dependent on ant protection than myrmecophiles; $;^{2,8,14}$ although several studies failed to find empirical support for the hypothesis that the foliage of obligate myrmecophytes lack secondary compounds required for their direct defense. ${ }^{9}$ Nevertheless, most obligate myrmecophytes suffer from dramatic leaf damage in the absence of a defending ant colony. ${ }^{2}$

The type and location of food rewards differ among genera. A number of myrmecophytes only produce FBs, such as Cecropia, Piper, and Macaranga. By contrast, Mesoamerican and African Acacia provide EFNs and FBs (Table 2) to their resident ants. Myrmecophyte-inhabiting ant colonies, in return, provide an intensive defensive service against herbivores, ${ }^{16-18}$ pathogens, ${ }^{19-21}$ and competing or parasitic plants $^{16,18}$ or supply nutrients via debris accumulation or defecation. ${ }^{22,23}$

Table I Rewards provided by myrmecophytic plants

Extrafloral nectaries: secretory tissues generally located on vegetative tissues and are not involved in pollination. Nectar secreted is a mixture of compounds usually dominated by sugars and amino acids.

Food bodies: cellular structures that serve as rewards for ants, and are rich in lipids and proteins.

Domatia: plant structures that serve as nesting space for ants. All ant-myrmecophyte symbiotic associations have one thing in common, that is plants provide domatia, such as hollow thorns, petioles, stems, or modified leaves to their inhabitant ants.

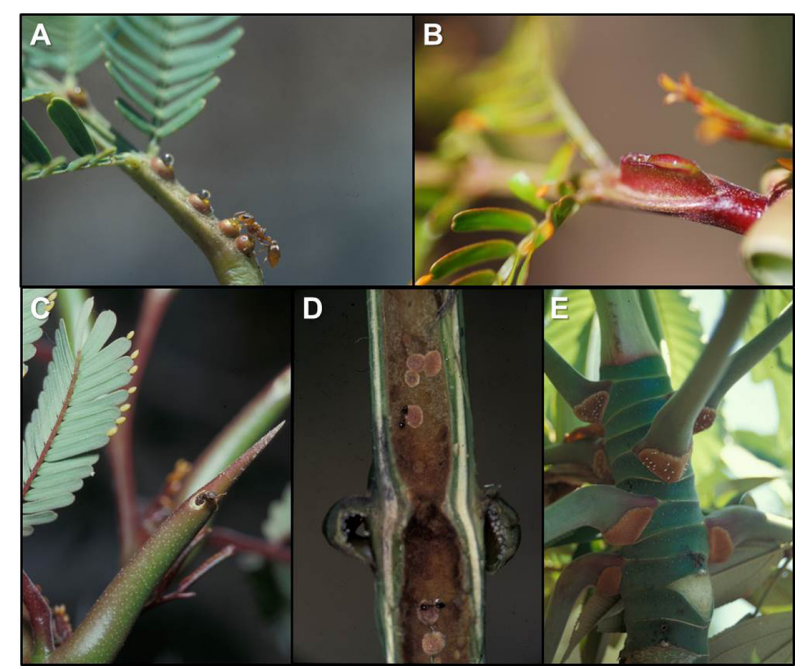

Figure I Rewards produced by myrmecophytic plants to establish stable obligate symbiotic mutualisms with ants.

Notes: Extrafloral nectar of Acacia hindsii (A) and Acacia cornigera (B). Food bodies and a hollow thorn of Acacia sp. (C). A hollow stem of Macaranga bancana (D). Food bodies at the base of a leafstalk in Cecropia mexicana (E).

In this review, we focus on the anatomical features as well as on the physiological and ecological functions of the rewards that myrmecophytes offer to maintain stable symbiotic mutualisms with ants. We also show how these rewards exhibit adaptive traits such as anatomical features and specific chemical components that match the special requirements of the consumers and, thus, allow for an optimized trading of rewards versus services.

\section{Extrafloral nectaries}

Nectaries are structures located on the surface of terrestrial plants that secrete aqueous sugar-rich solutions for attracting mutualists. Depending on their localization and ecological role, nectaries are divided into floral (F) and extrafloral (EF) nectaries. $F$ nectaries are localized in flowers and serving pollination, while EF nectaries are localized on the aerial vegetative organs and usually perform defensive functions. ${ }^{24} \mathrm{EF}$ nectaries are not involved in pollination and mainly attract ants and provide them with nutrition. ${ }^{25}$ These nectaries have been reported in 108 families of flowering plants and in four families of ferns, ${ }^{26}$ but they are particularly most abundant and diverse in the orders Malpighiales and Fabales. ${ }^{26,27}$ EF nectaries are widespread and evolutionary labile traits that have evolved independently in many unrelated plant taxa and at different times during their evolutionary history. ${ }^{26,28}$ They can occur not only on the petiole, rachis of compound leaves, leaf margins, and stipules, but also on the shoot or within inflorescences (Table 2). EF nectaries are also present in 
Table 2 Plant-ant obligate interactions in six plant groups

\begin{tabular}{|c|c|c|c|c|c|c|}
\hline & $\begin{array}{l}\text { Mesoamerican } \\
\text { Acacia sp. } \\
\text { (Leguminosae) }\end{array}$ & $\begin{array}{l}\text { African Acacia sp. } \\
\text { (Leguminosae) }\end{array}$ & $\begin{array}{l}\text { Macaranga sp. } \\
\text { (Euphorbiaceae) }\end{array}$ & $\begin{array}{l}\text { Cecropia sp. } \\
\text { (Moraceae) }\end{array}$ & $\begin{array}{l}\text { Piper sp. } \\
\text { (Piperaceae) }\end{array}$ & $\begin{array}{l}\text { Leonardoxa } \\
\text { africana } \\
\text { (Leguminosae) } \\
\end{array}$ \\
\hline $\begin{array}{l}\text { Mutualistic ant } \\
\text { partner }\end{array}$ & Pseudomyrmex & Crematogaster & Crematogaster & Azteca & Pheidole & Petalomyrmex \\
\hline $\begin{array}{l}\text { Position of } \\
\text { extrafloral nectar }\end{array}$ & Leaf base & Leaf base & Absent & Absent & Absent & Leaf base \\
\hline Food bodies & $\begin{array}{l}\text { Multicellular; } \\
\text { rich in proteins }\end{array}$ & Multicellular & $\begin{array}{l}\text { Multicellular; } \\
\text { rich in lipids }\end{array}$ & $\begin{array}{l}\text { Multicellular; rich in } \\
\text { glycogen and lipids }\end{array}$ & $\begin{array}{l}\text { Single cells; } \\
\text { rich in lipids }\end{array}$ & Absent \\
\hline Domatia & Hollow thorn & Hollow thorn & Hollow stem & Hollow stem & Hollow stem & Hollow internodes \\
\hline Ant service & Defense & Defense & Defense & $\begin{array}{l}\text { Defense, } \\
\text { nutrient supply }\end{array}$ & $\begin{array}{l}\text { Defense, } \\
\text { nutrient supply }\end{array}$ & Defense \\
\hline
\end{tabular}

Notes: The American and African Acacia spp. are now assigned to the genera Vachellia, Senegalia, Mariosousa, and Acaciella. ${ }^{133,134}$ Here, we will use the genus name Acacia to refer to American and African lineages to maintain consistency with previous studies.

Nepenthes plants, in which EFN attract arthropods that lose their foothold and fall into the digestive fluid of Nepenthes pitcher, ${ }^{29,30}$ thus serving as a trapping mechanism for these carnivorous plants.

Nectaries can widely vary in complexity and range from simple glandular trichomes without a well-defined internal structure to complex glands that are vascularized by both phloem and xylem. ${ }^{31}$ Nectaries can be categorized into seven groups according to their structure: ${ }^{32,33}$ 1) formless nectaries (with no structural specialization), 2) flattened nectaries (closely pressed against the fundamental tissue), 3) pit nectaries (glandular tissue sunken in tissues of other organs), 4) hollow nectaries (deep cavities in other plant organs with a narrow channel extending to the surface), 5) scale-like nectaries (glandular trichomes modified for nectar production and secretion), 6) elevated nectaries (well-defined glands that rise above the ground mesophyll tissue), and 7) embedded nectaries (secretory tissue totally inserted in tissues). The simplest nectaries, such as formless, pit, and scale-like nectaries, are usually nonvascularized and without a well-defined internal structure; these simple nectaries can be seen in a recently discovered example in the family Brassicaceae. ${ }^{34}$ By contrast, flattened, hollow, and elevated nectaries are usually vascularized. ${ }^{32,33}$

Anatomically, three different tissues can be generally recognized in EFNs: the epidermis, nectary parenchyma, and subnectary parenchyma (including the vascular bundles branching off from the leaf vascular system) (Figure 2). ${ }^{35}$ The epidermis is composed of polyhedric cells that are normally smaller than the parenchymal cells. A thick cuticle normally covers epidermal cells of EFNs, and the nectar secretion usually occurs through the rupture of the cuticle. ${ }^{35,36}$
In other cases, the nectary epidermis can possess different secretory structures such as trichomes ${ }^{37}$ or stomata, which remain constitutively open. ${ }^{38,39}$ The secretory cells are located below the epidermis and correspond to the nectary parenchyma, which is commonly composed of a few to several layers of small cells with thin walls, conspicuous nuclei, and dense cytoplasm. ${ }^{35}$ The abundance of mitochondria and ribosomes increases at the moment of nectar secretion, indicating increased energy requirements for nectar production. The subnectary parenchyma is located below the nectar parenchyma and is composed of large cells containing big vacuoles. The subnectary parenchyma is generally rich in chloroplasts, and its cytoplasm is not as dense as that of secretory cells. ${ }^{35}$ Vascular bundles are adjacent to the subnectary parenchyma. EF nectaries often receive no direct vascular supply into the secretory cells; ${ }^{33}$ therefore, the nectar secretion usually does not comprise a simple transport from the phloem into the nectary cells. Instead, photosynthates seem to be uploaded from the phloem into the subnectary parenchyma and then symplastically transported into the secretory cells. ${ }^{40}$ The subnectary parenchyma (with big vacuoles) is likely to be

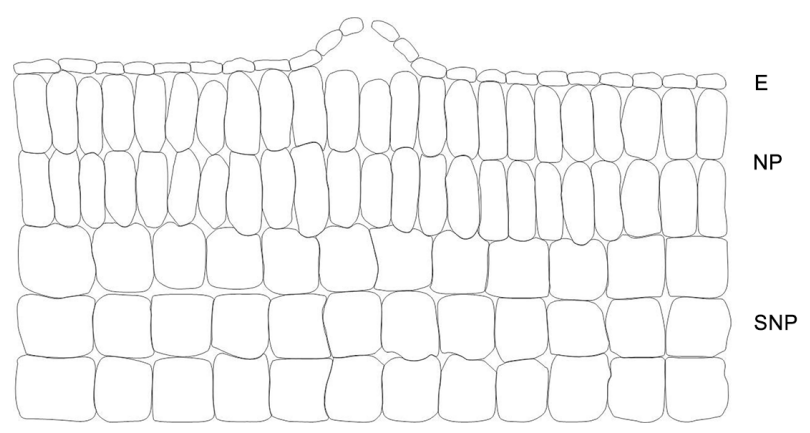

Figure 2 Anatomical tissues typically recognized in extrafloral nectaries. Abbreviations: $\mathrm{E}$, epidermis; NP, nectary parenchyma; SNP, subnectary parenchyma. 
involved in the storage of carbohydrates, whereas the nectary parenchyma would be mostly involved in the processing and secretion of the pre-nectar. Among myrmecophytes, Acacia spp. and Leonardoxa africana possess EF nectaries, although they differ considerable in their structures. Acacia cornigera possesses elongated, vascularized EFNs that are elevated from the surrounding tissues, ${ }^{41}$ whereas L. africana presents embedded, nonvascularized EFNs. ${ }^{28}$

\section{Formation and secretion of nectar}

Nectar has long been considered as "secreted phloem sap", which might be modified by nectary cells. ${ }^{42-44}$ Carbohydrates (mono-, di-, and trisaccharides) are the dominant component of nectar and are usually accompanied by much lower amounts of free amino acids (AAs), proteins, lipids, and secondary metabolites. ${ }^{45,46}$ The chemical components of nectar have two main functions: 1) attract mutualists and 2) generate indirect protection against non-mutualistic organisms, including nectar robbers and infecting microorganisms. ${ }^{45,46}$ Sugars, AAs, and volatile organic compounds mostly serve the attractive function, ${ }^{46,47}$ whereas other compound classes such as proteins, nonprotein AAs, and secondary metabolites are involved in the protection of EFN. ${ }^{48}$

In general, we can distinguish three different phases of nectar formation and secretion: 1) carbohydrate uploading and storage, 2) processing of pre-nectar and synthesis of noncarbohydrate components, and 3) nectar secretion. ${ }^{31,40}$ Carbohydrates required for nectar formation appear to be either uploaded from the phloem to the parenchyma tissue where they are stored and/or processed-, ${ }^{49,50}$ synthesized in the nectary parenchyma itself, ${ }^{51}$ or derived from photosynthetic activity in the nectary itself. ${ }^{52}$ Recent studies confirmed earlier observations $^{53}$ and highlighted invertases as central players in the formation, secretion, and control of the chemical composition of nectar. ${ }^{51,54-56}$ Even post-secretory processes can change the composition of nectar. For example, in Acacia EFN, sucrose is eliminated from nectar by invertases that are secreted into the liquid nectar itself. ${ }^{53,55}$ Although it still remains to elucidate where and how other nectar components, such as secondary metabolites and AAs, are synthesized, important metabolic and synthesis processes required for the EFN secretion occur in the nectary itself. ${ }^{51}$ In fact, protein accumulation, invertase activities, and gene expression in the nectary tissue of Acacia cornigera temporally coincided with the concurrent secretory activity. Similar observations have been found for F nectaries of Nicotiana tabacum and Arabidopsis, in which all the genes required for the full nectar synthesis and secretion are expressed in the nectary tissue itself. $^{50,57-60}$ Moreover, ultrastructural studies in EFNs of Vigna unguiculata demonstrated the presence of protein-rich inclusions in secretory cells. ${ }^{61}$

The exchange of rewards and services in ant-plant mutualisms can be optimized when rewards are only produced in the presence of - or allocated toward - the legitimate consumers. For example, most Acacia myrmecophytes reduce the amounts of EFN produced when they are not well defended by the resident ants. ${ }^{62}$ Moreover, a higher investment in EFN increases the number of worker ants patrolling on the leaves as well as ant aggressiveness. ${ }^{63-65}$ In myrmecophytic Acacia spp., higher EFN production enhanced the recruitment of Pseudomyrmex ferrugineus workers to the leaves and was positively related to ant-mediated protection against nectarrobbing bees, ${ }^{65}$ non-defending exploiting ant species, ${ }^{66}$ and also against mimics of herbivores. ${ }^{65}$ Thus, it seems that the amount of secreted EFN can be adjusted to ensure that the plant obtains the maximum mutualistic benefits minimizing costs, which are assumed to be involved with nectar production. ${ }^{67}$ Nevertheless, it is still unknown which exogenous cues, besides herbivore-inflicted damage, the plant is able to sense in order to adjust EFN secretion to the current needs. Preliminary observations using Macaranga tanarius and poplar indicate that certain EF nectaries might be able to cease the secretion in the absence of consumers or, perhaps, reabsorb unconsumed nectar. ${ }^{36,68}$ Thus, another emergent question is whether EF nectaries can sense unconsumed nectar. Ultrastructural observations in F nectaries suggest that reabsorption requires energy; numerous mitochondria have been observed in the nectary parenchyma and epidermis. ${ }^{69,70}$ Experimental evidence for reabsorption by EF nectaries has been reported only for poplar so far, ${ }^{36}$ although general considerations make it tempting to speculate that reabsorption might be a common phenomenon in EFN. In general terms, reabsorption requires that the nectar remains in contact with the nectary surface and that the nectaries remain alive and attached to the plant even after the active process of nectar secretion. ${ }^{71}$ These requirements are met by most EF nectaries, a reason for which it appears likely that the phenomenon of reabsorption occurs also for EFN. Further studies with EFN should consider using ${ }^{14} \mathrm{C}$-labeled sugars in order to gain information, parallel to $\mathrm{FN}$, about the uptake and reallocation of EFN contents to other plant organs. ${ }^{69,72}$

\section{Food bodies}

FBs are cellular structures that contain a variety of nutrients such as proteins, lipids, and carbohydrates, and can be produced by myrmecophytic and myrmecophilic plants. In most 
cases, FBs are ontogenetically derived from leaf tissues; nevertheless, they can also be derived from shoot epidermal cells, trichomes, and other structures at the plant surface. ${ }^{73,74}$ FBs have been described from a diverse range of unrelated myrmecophytes, and different terms have been coined for their denomination: "Müllerian bodies" are found in Cecropia ${ }^{75}$ "Beltian bodies" in Acacia, ${ }^{73,74}$ "Beccarian bodies" in Macaranga ${ }^{76}$ and "Pearl bodies" in Piper ${ }^{77}$ However, similar ultrastructural characteristics in different types of FBs highlight that "Müllerian", "Beltian", "Beccarian", and "Pearl bodies" are likely to share the same ecological function as energy-rich structures that serve as a reward for defending ants. Since all of them appear to have the same ecological role, we will use the term "FBs" to refer to all of them. FBs have been reported in 90 plant genera from 34 families of angiosperms. ${ }^{78}$ However, in contrast to EFN, FBs have received much less scientific consideration, and anatomical, physiological, and ecological information has been collected almost exclusively from obligate myrmecophyte plants. But Yamawo and Hada recently reported ${ }^{79}$ reported the presence of FB-like structures on a myrmecophilic plant.

FBs are located in different zones on the plant surface, have multiple anatomical origins, and differ in their morphology and development, depending on the myrmecophyte plant species. They can range from single epidermal cells without any involvement of the underlying parenchyma, eg, in Piper $^{80}$ (Figure 3A), to cells with a specialized internal differentiation, connected to the vascular tissue, eg, in $A$. cornigera $^{73,74}$ (Figure 3B). Ultrastructural studies have shown similar aspects in FB cells from different genera during their development. The cells contain a dense cytoplasm, numerous mitochondria, and a well-developed endoplasmic reticulum. ${ }^{74,80,81}$ The latter characteristics indicate that FBs are metabolically active cells that perform the functions of synthesis and storage of energy-rich nutrients: a source of nutrition for ants. ${ }^{82,83}$ In fact, in Acacia FBs, the cortical cells represent the dominant fraction and are rich in mitochondria, dictyosomes, rough endoplasmic reticulum, and plasmodesmata, which indicates their intensive metabolic activity ${ }^{74}$ Furthermore, a recent proteomic study confirmed the presence of multiple metabolic enzymes in the FBs of Acacia cornigera ${ }^{84}$ which indicates that these FBs might be able to synthesize a large part of the required nutrients for ants in an autonomous manner.

FBs in myrmecophytes are rich in lipids ${ }^{85,86}$ and proteins, ${ }^{86,87}$ whereas the amount of carbohydrates is less ${ }^{87,88}$ (Table 2). Differences in FB composition among myrmecophytes appear to be related to the specific nutritional needs of their associated
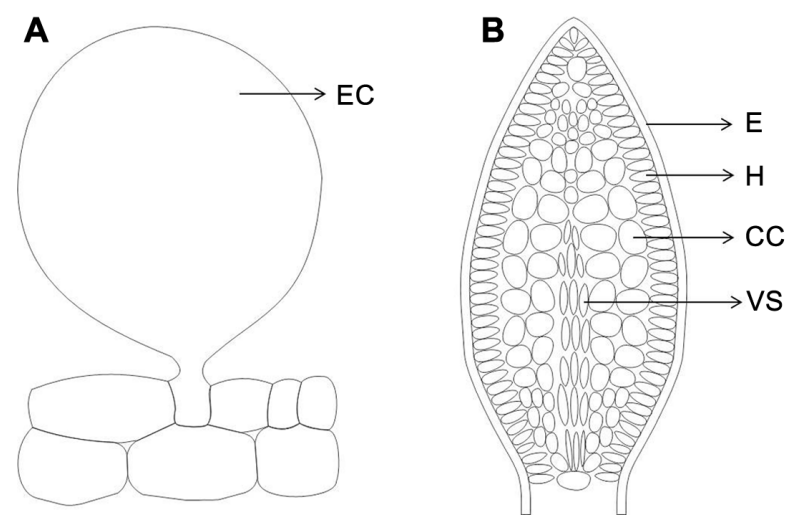

Figure 3 Comparison of the anatomical structure of food bodies in Piper and Acacia cornigera.

Notes: In Piper (A), FBs are anatomically simple and involve the enlargement of single epidermal cells without any involvement of the underlying parenchyma. In Acacia cornigera (B), FBs are anatomically differentiated and show a specialized internal differentiation of cells. They are connected to the vascular tissue.

Abbreviations: EC, epidermal cell; E, epidermis; CC, cortex cell; FBs, food bodies; $\mathrm{H}$, hypodermis, VS, vascular system.

ant species. Studies comparing the chemical content of FBs between myrmecophytic and myrmecophilic plants also support the hypothesis that the composition of FBs reflects the nutritional requirements of their respective ants. Although high levels of lipids and proteins are commonly present in FBs of myrmecophytes, ${ }^{85-87}$ FBs of myrmecophilic plants are characterized by high contents of low-molecular soluble compounds, such as sugars and AAs, which act as an attractant of generalist ants. ${ }^{85}$ Consistently, FBs of myrmecophytic Macaranga and Cecropia are not as attractive to generalist ants as to symbiotic ants. ${ }^{85,89}$ The latter fact highlights that FBs are not equally suitable for specialized and generalist ants, and raises the question whether the chemical composition of FBs prevents the consumption or exploitation by non-mutualists. But, how can the host plant sense the presence of the right mutualistic partner? General considerations predict that FBs should be only produced in the presence of the respective ant mutualists. Indeed, some evidences show that mutualistic ants can stimulate the production of FBs in several genera of host plants. ${ }^{3,90-92}$ For example, the unicellular FBs of Piper cenocladum are considerably more abundant in plants with the symbiotic ant Pheidole bicornis than in ant-free plants. ${ }^{3}$ Moreover, nonsymbiotic ants failed to trigger the production of FBs in Piper, ${ }^{3,90}$ which indicates that a chemical signal is likely to cause this specific allocation of the reward to reciprocating mutualists. Similarly, ant-inhabited Macaranga triloba (now bancana) plants produced more FBs than ant-free ones, even in the absence of herbivores. ${ }^{83}$ However, in ant-free Cecropia plants, manual collection stimulated the production of new FBs ${ }^{92}$ which indicates that mechanical removal can 
be enough to stimulate FB production, at least in this genus. Taken together, it seems that myrmecophytes are able to sense the presence and identity of ants and, perhaps, identify the defensive activity of the colonizing ants and allocate FBs mainly to the reciprocating mutualistic ants. However, the factors that control FB production quantitatively and qualitatively in order to allow their cost-efficient allocation still remain to be investigated.

Recent physiological studies have reported that specific components in the FBs of myrmecophytic Acacia, similar to the chemistry of the EFN, also serve as a filter that hinders consumption by non-mutualists. FBs of Mesoamerican Acacia myrmecophytes contain protease inhibitors that successfully inhibit the digestive protease activity in the guts of non-mutualistic organisms such as seed-feeding beetles and parasitic ants of the species Pseudomyrmex gracilis. ${ }^{84}$ Considerably lower proteolytic activity was observed in the gut of the larvae of $P$. gracilis $^{93}$ after the consumption of Acacia FBs. By contrast, larvae of mutualistic ants of $P$. ferrugineus possess a protease (chymotrypsin 1) in their gut that is insensitive to the inhibitors and, thus, is able to metabolize the proteins of Acacia FBs. ${ }^{84}$

\section{Domatia}

Domatia are plant structures that usually assume the form of depressions or cavities of various types, such as pouches of leaf tissue or domes with an opening on the top, hollow thorns, or hollow twigs. ${ }^{94}$ The term "ant domatia" is used for all physical plant structures that appear to be adaptations that facilitate ant nesting. ${ }^{95}$ Benson ${ }^{96}$ distinguished two types of domatia: primary and secondary. Primary domatia are derived from preformed cavities that can also be observed in plants with no mutualism with ants, including hollow stems, petioles, or thorns. By contrast, secondary domatia are modified structures and considered as distinct organs, eg, leaf pouches resulting from the modification of the leaf lamina. Among the plantprovided rewards to ants, domatia are the least studied, but not the least important; in fact, domatia represent the key factor for the evolution of obligate plant-ant mutualisms. ${ }^{97}$ Primary domatia have been described as stem domatia in Cecropia ${ }^{2}$ and Macaranga, ${ }^{97}$ hollow leafstalks in Piper,${ }^{98}$ hollow thorns in Acacia $^{82}$ and hollow internodes in Leonardoxa. ${ }^{99}$ Myrmecophytic plants produce domatia independently of the presence of ants; nevertheless ants can enlarge the nesting space and, in most cases, must actively open an entrance hole to get access. Myrmecophytic plants can facilitate hole boring by providing special thin zones in the domatium wall, called prostomata, ${ }^{4}$ which lack vascular or lignified tissue. ${ }^{4}$ It has been described for Cecropia, ${ }^{89}$ Leonardoxa, ${ }^{4}$ and Macaranga.${ }^{100}$ Plant anatomy, in addition to the behavior of ants, highly contributes to the formation of suitable domatia and facilitates specific interactions between myrmecophytes and their reciprocating ant species. Comparative studies have shown striking anatomical differences in homologous structures between species that harbor ants and those that do not. For example, myrmecophytes of the genus Piper present soft heterogeneous pith, in which a large central area has relatively large cells that lack intracellular crystals - important factors that facilitate the excavation of these cauline domatia by Pheidole ants. ${ }^{98}$ In Piper, excavated stems present a suberized layer of wound response tissue (differentiated cells that are fixed in morphology and development) on the cavity walls ${ }^{101}$ (Figure 4A). By contrast, myrmecophilic plants of the same genus are characterized by homogeneous piths with the presence of crystals in the central zone, which appear to function as mechanical support (Figure 4B). Thus, it seems that the specificity of the ant-plant interaction is determined by the structure and arrangement of the tissues in domatia cavities. ${ }^{102}$

Secondary domatia have been less studied than primary; nevertheless, morpho-anatomical differences between leaf pouches and the respective lamina in neotropical myrmecophytes have been described. ${ }^{103,104}$ A study comparing leaf domatia of three neotropical myrmecophytes (Hirtella physophora, Maieta guianensis, and Tococa guianensis) revealed similar morpho-anatomical characteristics for the domatia of all the species - a compact structure characterized by numerous layers of parenchymatous tissue, a lack of differentiation between the palisade and spongy parenchyma, and a low density of chloroplasts among parenchyma cells. ${ }^{104}$ Moreover, the leaf domatia is thicker and more resistant (Figure 5A) than the lamina (Figure 5B) due to the thicker layer of
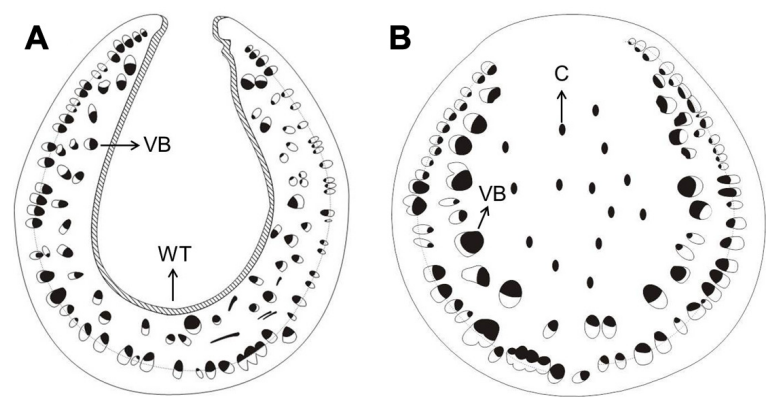

Figure 4 Comparison of the anatomical structure between a hallow and an unhollowed stem.

Notes: The figure depicts differences in the anatomical structure between a hollow stem of a myrmecophytic plant $(\mathbf{A})$ and an unhollowed stem of a myrmecophilic plant (B). Copyright (C) 2007 The Botanical Society of America.Adapted from Tepe EJ, Vincent MA, Watson LE. Stem diversity, cauline domatia, and the evolution of antplant associations in Piper sect. Macrostachys (Piperaceae). Am J Bot. 2007;94:I-1 I. ${ }^{98}$ Abbreviations: C, crystal; VB, vascular bundle; WT, wound tissue. 


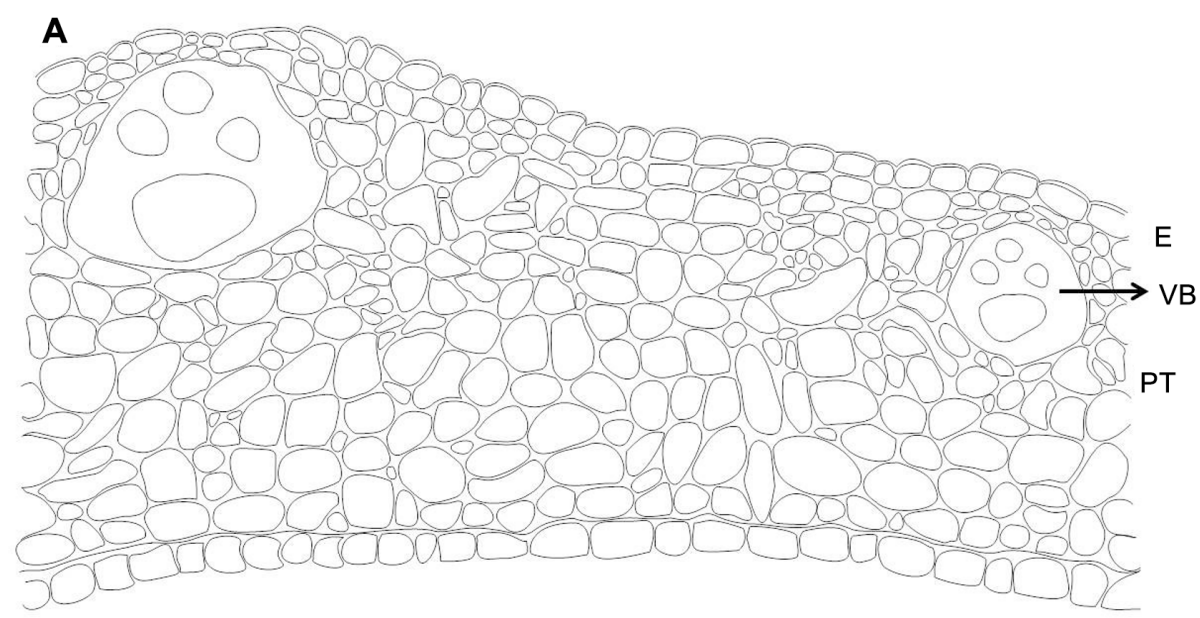

B

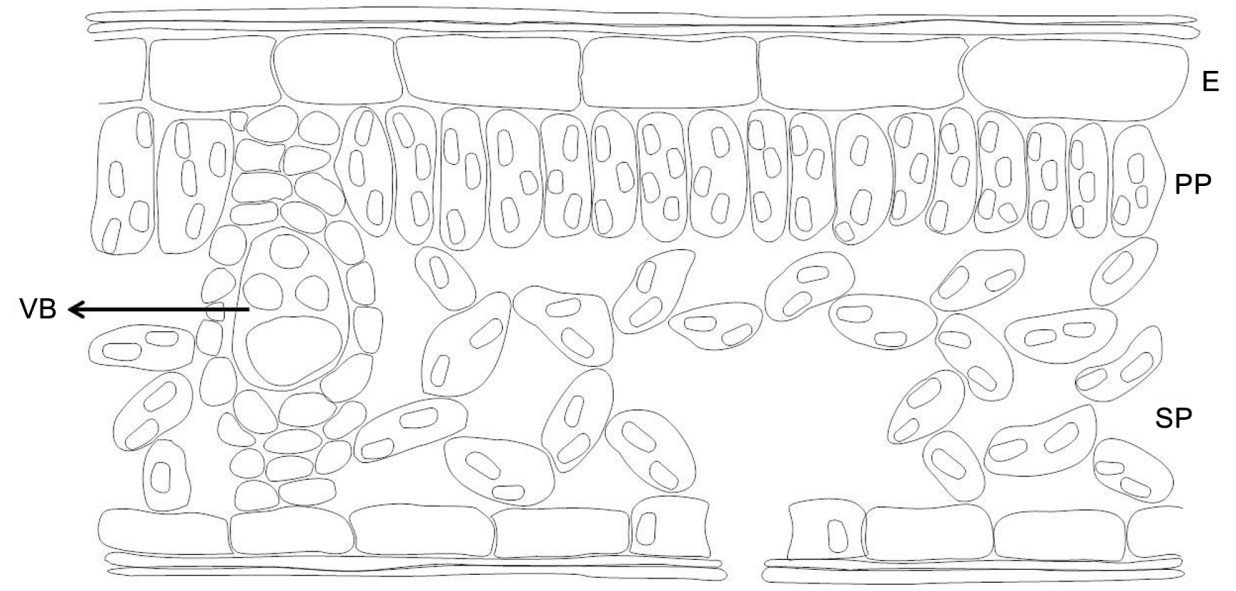

Figure 5 Comparison of the anatomical structure of an ant domatia with that of a leaf lamina.

Notes: The figure depicts differences in the anatomical structure between an ant domatia (A) and a leaf lamina (B).

Abbreviations: PP, palisade parenchyma; E, epidermis; PT, parenchymatous tissue; PP, palisade parenchyma; SP, spongy parenchyma; VB, vascular bundle.

parenchymatous tissue, larger epidermal cells, and lignified sclerenchyma fibers. Thus, these leaf pouches have evolved to become more specialized to house ants than in having a photosynthetic function. In addition, stomata were always present in the domatia cavity, which suggests a potential exchange of gases between the ant and the plant. ${ }^{22}$

Myrmecophytes invest a large amount of tissue to domatia formation, which could be potentially useful for the storage of water and assimilates, or even for photosynthesis. Nevertheless, a flow of resources does not only occur from plants to ants, but also from ants to plants. ${ }^{.2,23,105,106}$ Nutrient fluxes from ants to plants have been demonstrated in epiphytic myrmecophytes, ${ }^{22,105}$ geophytic myrmecophytes, ${ }^{107}$ and obligate "defensive" myrmecophytes such as Cecropia ${ }^{108}$ and Piper $^{23}$ In fact, domatia are characterized as particular microenvironments with higher $\mathrm{CO}_{2}$ and nitrogen content and, thus, can potentially act as places in which gas exchange and nutrient flux occur between resident ants and the host plant. Using stable isotope analysis, it has been demonstrated that ant respiration is an additional source of $\mathrm{CO}_{2}$ in leaves of Dischidia major. Approximately $40 \%$ of the carbon in occupied plant leaves of D. major was derived from ant-related respiration, and almost $30 \%$ of the nitrogen in the host plant was derived from debris that the ants had deposited in the leaf cavities. ${ }^{22}$ Similar results were reported for Piper myrmecophytes, in which $25 \%$ of the nitrogen ingested by the ants was incorporated into the plants. ${ }^{23}$ In the obligate myrmecophyte Cecropia, even $93 \%$ of the nitrogen in antoccupied host plants appeared to be derived from ant debris, according to measurements of the natural abundances of stable isotopes. ${ }^{108}$ Myrmecophytes can produce domatia regardless of the activity or presence of their ant mutualists. Nevertheless, ants were able to induce domatia production in Vochysia vismiaefolia. ${ }^{109}$ Moreover, ant-free Mesoamerican Acacia myrmecophytes that are colonized by exploiting ants tend to exhibit a much lower density of domatia than plants 
that are inhabited by a defending Pseudomyrmex species (Martin Heil, CINVESTAV, personal observations, November, 2008). Thus, it seems that, similar to the induction of EFN and FB production, plants are also able to sense the presence of ants in order to stimulate the production of the adequate nesting space.

\section{Costs of symbiotic plant-ant interactions and evolutionary perspectives}

Mutualisms are defined as interactions that are beneficial for both partners. Nevertheless, they cause costs to both partners, which, in the long run, need to be counterbalanced by the respective benefits. The benefits to plants and ants of engaging in an obligate mutualism have been previously discussed. Plants obtain defense and nutrient uptake from ants, while ants obtain food and shelter from plants. Nevertheless, the maintenance of the ant colony can impose costs on myrmecophytes when the allocation of limited resources of food rewards or housing for ants entails negative effects on host plant fitness. ${ }^{10}$ Likewise, defending and aggressive behavior of symbiotic ants can also imply ecological costs to the host plant through an effect on the interaction of the host plant with other beneficial organisms. For example, ants can deter pollinators ${ }^{63}$ or destroy reproductive tissues, ${ }^{111-113}$ which finally can significantly affect host plant fitness.

Costs associated with the production of FBs have been quantified in some studies. FB production by the myrmecophytic Ochroma pyramidale represented approximately $1 \%$ of leaf biomass, ${ }^{114}$ whereas FB production by the myrmecophyte Macaranga bancana represented approximately $5 \%$ of the total aboveground biomass production. In terms of lipids, FB production even represented $30 \%$ of aboveground plant biomass production by the same species. ${ }^{83}$ Fitness costs of EFN secretion in the absence of herbivores could never be experimentally detected, ${ }^{114-116}$ but nectar production has also been assumed to consume large parts of the daily-assimilated carbon, at least during the flowering phase. ${ }^{67}$ Although the allocation costs of EFN secretion in myrmecophytes have been not investigated so far, the secretion of EFN on young leaves of Ricinus communis and Phaseolus lunatus required the transport of assimilates from mature to younger leaves, ${ }^{117}$ and shading of the leaves decreased concurrent EFN secretion rates in R. communis. ${ }^{118}$ These observations clearly indicate that EFN competes for assimilates with other parts of the plant.

Indirect defense via ant-plant mutualisms that depend on FBs or domatia frequently trades off against direct chemical defense, ${ }^{119}$ which is another indicator of high costs of this particular defensive strategy. Indeed, recent studies have reported that maintaining ant colonies is cost-effective for the myrmecophytes Acacia drepanolobium and Cordia nodosa. ${ }^{110,120}$ For example, in the presence of herbivores, symbiotic Allomerus octoarticulatus ants increased the plant growth of C. nodosa, whereas in the absence of herbivores, plants of $C$. nodosa with ants were $18 \%$ shorter and had 40\% fewer domatia and 36\% fewer leaves than plants without ants. ${ }^{110}$ Furthermore, African Acacia trees, from which Acacia ant spp. were removed, suffered greater attack from herbivores, but grew faster over the course of the experiment than trees in which ants were present. ${ }^{120}$ Therefore, although several meta-analyses unambiguously demonstrated a generally positive outcome of defensive ant-plant interactions, ${ }^{119,121-123}$ the costs of maintaining the mutualism under certain environmental circumstances can exceed the benefits that host plants can gain from symbiotic ants.

If maintaining an ant colony implies a cost for the host plant, we can expect that the investment in food rewards and housing should be subject to stabilizing selection, ie, there must be an optimal investment that balances between the benefits of having ants and the cost of feeding and housing them. Thus, plants can minimize the allocation of resources to ant rewards, investing more in growth and reproduction, at the expense of the mutualism. The multiple strategies described earlier concerning: 1) the optimized chemical contents of EFN and FBs; 2) the specific production of FBs, EFN, and domatia in the presence of reciprocating mutualists; and 3) the production of EFN and even domatia in response to herbivory (ie, when defense is actually required) indicate that ant-plant mutualisms have adapted to meet these needs and optimize the investments that are associated with an obligate indirect defense by ants.

The evolutionary stability of mutualisms requires the action of different mechanisms, ${ }^{124}$ which reduce the selection for cheating and favor the maintenance and stability of the mutualism. As ant-plant mutualisms are likely to be stabilized via partner fidelity mechanisms, ${ }^{6}$ it is assumed that myrmecophytes are unlikely to cheat on the allocation of resources to ant rewards over evolutionary time. ${ }^{78}$ The concept of partner fidelity assumes that cooperation will be favored when species stay together in stable associations that align their fitness interests. ${ }^{124}$ Indeed, a positive feedback loop formed by fitnessrelevant traits of both ants and plants has been described for the Acacia-Pseudomyrmex mutualism. ${ }^{62}$ Thus, from the plant's point of view, feeding and housing ants are probably costly, but nevertheless, these costs are counterbalanced, because the benefits provided by the host plant will feedback to benefits provided by symbiotic ants. Consequently, several meta-analyses have shown that defending ants very rarely have negative net effects on their host plants, ${ }^{122,123,125}$ suggesting that the benefits received by host plants usually exceed the costs of 
maintaining ants. Experimentally, it has been shown that an increase in the secretion and concentration of EFN in Mesoamerican Acacia myrmecophytes positively correlates with ant recruitment, ant aggressiveness, and a better protection provided by the mutualistic ants, ${ }^{65}$ and that larger investment in EFN shifts the competitive balance among mutualists and exploiters toward a dominance of the defending mutualists. ${ }^{66}$ Therefore, it is highly probable that natural selection will favor mutualists more than cheaters, because a healthy host automatically feedbacks benefits to its symbionts. ${ }^{124,126}$

Even when the stability of mutualisms depends on general mechanisms that counteract the selective incentive to cheat, each plant-ant symbiosis evolved, and has to be maintained in a particular ecological setting. Therefore, the costs and benefits for both partners can be affected by several factors, which can drive the cooperation of the mutualism. For example, the costbenefit ratio might depend on factors such as the ontogeny of the host plant or the ant colony, ${ }^{127,128}$ the availability of nutrients or light, ${ }^{128-130}$ or herbivore pressure. ${ }^{131}$ Therefore, understanding the particular ecological context within which individual ant-plant systems are functioning and evolving is central to predict the costs and benefits of the mutualism and to determine whether potential selective pressures for cheating can overcome selection for cooperation.

\section{Future steps and conclusion}

In summary, many phenotypic studies of multiple genera of ants and plants have demonstrated that ant-plant mutualisms show multiple signs of adaptations in the chemistry of food rewards, the structure of domatia, and the spatiotemporal patterns in the production of all these rewards. Together, these adaptations and specializations allow an optimized exchange of rewards and services among the participating partners and the stabilization of the mutualisms against invasion or de novo evolution by exploiters. Unfortunately, the underlying physiological and molecular mechanisms remain to be investigated, and we have not yet identified a single signal, or cue, that host plants use to identify their resident ants or to measure their defensive efficiency, or that plant-ants use to identify their hosts and judge on their (present and future) quality. Studies on myrmecophytic plants should turn attention to the physiology of plant rewards, particularly FBs and domatia, which have been less studied than EFN. We know that the anatomical and chemical features of these rewards match their physiological and ecological functions. Nevertheless, there is still a large gap in our understanding of how the plants at the mechanistic level regulate the production and composition of EFN, FBs, and domatia. Is reward production a specific response to the identity, or rather the action
Table 3 Outstanding questions

- How do myrmecophytic plants mechanistically regulate the production of extrafloral nectar, food bodies, and domatia?

- Do the rewards offered by myrmecophytic plants represent a specific response to the mutualistic ant partner?

- Which signal, chemical or molecular, is used by myrmecophytes to identify the appropriate partner?

- How are myrmecophytic plants able to sense the presence of nonmutualistic ants that enable them to cease the production of rewards?

- How do plants and ants judge the quantity and/or quality of the resources provided by the partner, in order to express phenotypic plasticity in the provisioning of rewards and services that regulate an efficient reciprocal rewarding system?

of the ant partner? Who has the control: the ant or the plant? Are partner manipulation effects at the phenotypic level common? Does the investment in attracting ants correlate with the benefits gained from the presence of protective ants? Which internal and external cues are sensed by plants to induce the production of rewards (see Table 3 for other outstanding questions.)

Defensive ant-plant mutualisms provide us with a taxonomic and functional diversity that represents the outcome of multiple (taxonomically and geographically independent) attempts to solve the same problem - maintain a stable and cost-effective indirect defense via mutualistic ants. The use of contemporary molecular methods, such as proteomics and transcriptomics, is no longer restricted to a handful of model plants. Several recent examples ${ }^{51,132}$ illustrate how these techniques can be applied to study phenomena of ecological relevance for ant-plant mutualisms at the molecular level and under realistic field conditions. Future studies should employ these techniques to identify the traits that ants and plants use to recognize each other and to control each other's phenotype for the sake of a stable, mutually beneficial interaction.

\section{Acknowledgments}

We thank David Lane, editor-in-chief of Research and Reports in Biodiversity Studies, for inviting us to write this review. We also thank Rodrigo Ríos for his valuable comments on an earlier version of this manuscript and Marco Figueroa for preparing the figures.

\section{Disclosure}

The authors report no conflicts of interest in this work.

\section{References}

1. Bronstein JL, Alarcon R, Geber M. The evolution of plant-insect mutualisms. New Phytol. 2006;172:412-428.

2. Heil M, McKey D. Protective ant-plant interactions as model systems in ecological and evolutionary research. Annu Rev Ecol Evol Syst. 2003;34: 425-453. 
3. Risch SJ, Rickson F. Mutualism in which ants must be present before plants produce food bodies. Nature. 1981;291:149-150.

4. Brouat C, Garcia N, Andary C, McKey D. Plant lock and ant key: pairwise coevolution of an exclusion filter in an ant-plant mutualism. Proc R Soc B Biol Sci. 2001;268:2131-2141.

5. Yu DW, Wilson HB, Pierce NE. An empirical model of species coexistence in a spatially structured environment. Ecology. 2001;82:1761-1771.

6. Orona-Tamayo D, Heil M. Stabilizing mutualisms threatened by exploiters: new insights from ant-plant research. Biotropica. 2013;45: 654-665.

7. Heil M, Barajas-Barron A, Orona-Tamayo D, Wielsch N, Svatos A. Partner manipulation stabilises a horizontally transmitted mutualism. Ecol Lett. 2014;17:185-192.

8. Seigler DS, Ebinger JE. Cyanogenic glycosides in ant-acacias of Mexico and Central America. Southwest Nat. 1987;32:499-503.

9. Heil M, Delsinne T, Hilpert A, et al. Reduced chemical defence in antplants? A critical re-evaluation of a widely accepted hypothesis. Oikos. 2002;99:457-468

10. Young TP, Stubblefield CH, Isbell LA. Ants on swollen thorn acacias: species coexistence in a simple system. Oecologia. 1997;109:98-107.

11. Palmer TM, Young TP, Stanton ML, Wenk E. Short-term dynamics of an acacia ant community in Laikipia, Kenya. Oecologia. 2000;123: 425-435.

12. Yu DW, Wilson HB, Frederickson ME, et al. Experimental demonstration of species coexistence enabled by dispersal limitation. JAnim Ecol. 2004;73(6):1102-1114.

13. Schmitz OJ, Hamback PA, Beckerman AP. Trophic cascades in terrestrial systems: a review of the effects of carnivore removals on plants. Am Nat. 2000;155:141-153.

14. Rico-Gray V, Oliveira PS. The Ecology and Evolution of Ant-Plant Interactions. Chicago, IL: University of Chicago Press; 2007.

15. Fiala B, Maschwitz U. Food bodies and their significance for obligate ant-association in the tree genus Macaranga (Euphorbiaceae). Bot $J$ Linn Soc. 1992;110:61-75.

16. Davidson DW, McKey D. Ant-plants symbioses: stalking the chuyachaqui. Trends Ecol Evol. 1993;8:326-332.

17. Fonseca CR. Herbivory and the long-lived leaves of an Amazonian ant-tree. J Ecol. 1994;82:833-842.

18. Federle W, Maschwitz U, Fiala B. The two-partner ant-plant system of Camponotus (Colobopsis) sp. 1 and Macaranga puncticulata (Euphorbiaceae): natural history of the exceptional ant partner. Insectes Soc. 1998;45:1-16.

19. Letourneau DK. Ants, stem-borers, and fungal pathogens: experimental tests of a fitness advantage in Piper ant-plants. Ecology. 1998;79: 593-603.

20. Heil M, Baumann B, Andary C, Linsenmair KE, McKey D. Extraction and quantification of "condensed tannins" as a measure of plant antiherbivore defence? Revisiting an old problem. Naturwissenschaften. 2002;89:519-524.

21. Gonzalez-Teuber M, Kaltenpoth M, Boland W. Mutualistic ants as an indirect defence against leaf pathogens. New Phytol. 2014;202:640-650.

22. Treseder KK, Davidson DW, Ehleringer JR. Absorption of ant-provided carbon dioxide and nitrogen by a tropical epiphyte. Nature. 1995;375: 137-139.

23. Fischer RC, Wanek W, Richter A, Mayer V. Do ants feed plants? A ${ }^{15} \mathrm{~N}$ labelling study of nitrogen fluxes from ants to plants in the mutualism of Pheidole and Piper. J Ecol. 2003;91:126-134.

24. Caspary R. De nectariis. 1848. The Bavarian State Library: Marcus; 1848.

25. Heil M. Extrafloral nectar at the plant-insect interface: a spotlight on chemical ecology, phenotypic plasticity, and food webs. Annu Rev Entomol. 2015;60:213-232.

26. Weber MG, Keeler KH. The phylogenetic distribution of extrafloral nectaries in plants. Ann Bot. 2013;111:1251-1261.

27. Bentley B, Elias TS. The Biology of Nectaries. New York: Columbia University Press; 1983.

28. Elias TS. Foliar nectaries of unusual structure in Leonardoxa africana (Leguminosae), an African obligate myrmecophyte. Am J Bot. 1980;67: $423-425$.
29. Moran JA. Pitcher dimorphism, prey composition and the mechanisms of prey attraction in the pitcher plant Nepenthes rafflesiana in Borneo. $J$ Ecol. 1996;84:515-525.

30. Merbach MA, Zizka G, Fiala B, Maschwitz U, Booth WE. Patterns of nectar secretion in five Nepenthes species from Brunei Darussalam, Northwest Borneo, and implications for ant-plant relationships. Flora. 2001;196:153-160.

31. Escalante-Pérez M, Heil M. Nectar secretion: its ecological context and physiological regulation. In: Vivanco J, Baluska F, editors. Secretions and Exudates in Biological Systems. Berlin: Berlin Springer; 2012: $187-220$.

32. Zimmermann J. Über die extrafloralen Nektarien der Angiosperm. Beihefte Botanisches Centralblatt. 1932;49:99-196.

33. Elias TS. Extrafloral nectaries: their structure and distribution. In: Bentley B, Elias TS, editors. The Biology of Nectaries. New York: Columbia University Press; 1983:174-203.

34. Mathur V, Wagenaar R, Caissard JC, et al. A novel indirect defence in Brassicaceae: structure and function of extrafloral nectaries in Brassica juncea. Plant Cell Environ. 2013;36:528-541.

35. Nepi M. Nectary structure and ultrastructure. In: Nicolson S, Nepi M, Pacini E, editors. Nectaries and Nectar. Dordrecht: Springer; 2007:129-166.

36. Escalante-Pérez M, Jaborsky M, Lautner S, et al. Poplar extrafloral nectaries: two types, two strategies of indirect defenses against herbivores. Plant Physiol. 2012;159:1176-1191.

37. Davis AR, Peterson RL, Shuel RW. Vasculature and ultrastructure of the floral and stipular nectaries of Vicia faba (Leguminosae). Can J Bot. 1988;66:1435-1448.

38. Galetto L, Bernardello LM. Extrafloral nectaries that attract ants in Bromeliaceae: structure and nectar composition Can J Bot. 1992;70: 1101-1106.

39. Falcão PF, de A Melo-de-Pinna GF, Leal IR, Almeida-Cortez JS. Morphology and anatomy of extrafloral nectaries in Solanum stramonifolium (Solanaceae). Can J Bot. 2003;81:859-864.

40. Heil M. Nectar: generation, regulation, and ecological functions. Trends Plant Sci. 2011;16:191-200.

41. Díaz-Castelazo C, Rico-Gray V, Ortega F, Angeles G. Morphological and secretory characterization of extrafloral nectaries in plants of coastal Veracruz, Mexico. Ann Bot. 2005;96:1175-1189.

42. Agthe C. Über die physiologische Herkunft des Pflanzennektars. Berichte der Schweizerischen botanischen Gesellschaft. 1951;61:240-274. German.

43. Lüttge U. Über die Zusammensetzung des Nektars und den Mechanismus seiner Sekretion. I. Planta. 1961;56:189-212.

44. De la Barrera E, Nobel PS. Nectar: properties, floral aspects, and speculations on origin. Trends Plant Sci. 2004;9:65-69.

45. Nicolson SW. Amino acid concentrations in the nectars of southern African bird-pollinated flowers, especially Aloe and Erythrina. J Chem Ecol. 2007;33:1707-1720.

46. González-Teuber M, Heil M. Nectar chemistry is tailored for both attraction of mutualists and protection from exploiters. Plant Signal Behav. 2009;4:809-813.

47. Gonzalez-Teuber M, Heil M. The role of extrafloral nectar amino acids for the preferences of facultative and obligate ant mutualists. J Chem Ecol. 2009;35:459-468.

48. González-Teuber M, Heil M. Pseudomyrmex ants and Acacia host plants join efforts to protect their mutualism from microbial threats. Plant Signal Behav. 2010;5:890-892.

49. Wenzler M, Hoelscher D, OertherT, Schneider B. Nectar formation and floral nectary anatomy of Anigozanthos flavidus: a combined magnetic resonance imaging and spectroscopy study. J Exp Bot. 2008;59: 3425-3434.

50. Kram BW, Carter CJ. Arabidopsis thaliana as a model for functional nectary analysis. Sex Plant Reprod. 2009;22:235-246.

51. Orona-Tamayo D, Wielsch N, Escalante-Perez M, et al. Short-term proteomic dynamics reveal metabolic factory for active extrafloral nectar secretion by Acacia cornigera ant-plants. Plant J. 2013;73:546-554. 
52. Lüttge U. Green nectaries: the role of photosynthesis in secretion. Bot J Linn Soc. 2013;173:1-11.

53. Zimmermann M. Über die Sekretion saccharosespaltender Transglukosidasen im pflanzlichen Nektar. Experientia. 1954;15:145-146.

54. Gaffal KP. How common is the ability of extrafloral nectaries to produce nectar droplets, to secrete nectar during the night and to store starch? Plant Biol. 2012;14:691-695.

55. Heil M, Rattke J, Boland W. Postsecretory hydrolysis of nectar sucrose and specialization in ant/plant mutualism. Science. 2005;308: $560-563$

56. Ruhlmann JM, Kram BW, Carter CJ. Cell wall invertase 4 is required for nectar production in Arabidopsis. J Exp Bot. 2010;61:395-404.

57. Carter $\mathrm{C}$, Thornburg RW. The nectary-specific pattern of expression of the tobacco Nectarin I promoter is regulated by multiple promoter elements. Plant Mol Biol. 2003;51:451-457.

58. Carter C, Thornburg RW. Is the nectar redox cycle a floral defense against microbial attack? Trends Plant Sci. 2004;9:320-324.

59. Liu G, Ren G, Guirgis A, Thornburg RW. The MYB305 transcription factor regulates expression of nectarin genes in the ornamental tobacco floral nectary. Plant Cell. 2009;21:2672-2687.

60. Liu G, Thornburg RW. Knockdown of MYB305 disrupts nectary starch metabolism and floral nectar production. Plant J. 2012;70:377-388.

61. Kuo J, Pate JS. The extrafloral nectaries of cowpea (Vigna unguiculata (L.) Walp): I. Morphology, anatomy and fine structure. Planta. 1985;166:15-27.

62. Heil M, González-Teuber M, Clement LW, Kautz S, Verhaagh M, Silva Bueno JC. Divergent investment strategies of Acacia myrmecophytes and the coexistence of mutualists and exploiters. Proc Natl Acad Sci U S A. 2009;106:18091-18096.

63. Ness JH. A mutualism's indirect costs: the most aggressive plant bodyguards also deter pollinators. Oikos. 2006;113:506-514.

64. Ness JH, Morris WF, Bronstein JL. For ant-protected plants, the best defense is a hungry offense. Ecology. 2009;90:2823-2831.

65. González-Teuber M, Bueno JC, Heil M, Boland W. Increased host investment in extrafloral nectar (EFN) improves the efficiency of a mutualistic defensive service. PLoS One. 2012;7:e46598.

66. Heil M. Let the best one stay: screening of ant defenders by Acacia host plants functions independently of partner choice or host sanctions J Ecol. 2013;101:684-688.

67. Southwick EE. Photosynthate allocation to floral nectar: a neglected energy investment. Ecology. 1984;65:1775-1779.

68. Heil M, Fiala B, Baumann B, Linsenmair KE. Temporal, spatial and biotic variations in extrafloral nectar secretion by Macaranga tanarius. Funct Ecol. 2000;14:749-757.

69. Nepi M, Ciampolini F, Pacini E. Development and ultrastructure of Cucurbita pepo nectaries of male flowers. Ann Bot. 1996;78:95-104.

70. Stpiczynska M, Milanesi C, Faleri C, Cresti M. Ultrastructure of the nectary spur of Platanthera chlorantha (Custer) Rchb. (Orchidaceae) during successive stages of nectar secretion. Acta Biologica Cracoviensia Series Botanica. 2005;47:111-119.

71. Búrquez A, Corbet SA. Do flowers reabsorb nectar? Funct Ecol. 1991;5:369-379.

72. Nepi M, Guarnieri M, Pacini E. Nectar secretion, reabsorption, and sugar composition in male and female flowers of Cucurbita pepo. Int J Plant Sci. 2001;162:353-358.

73. Rickson FR. Developmental aspects of the shoot apex, leaf, and Beltian bodies of Acacia cornigera. Am J Bot. 1969;56:195-200.

74. Rickson FR. The ultrastructure of Acacia cornigera L. Beltian body tissue. Am J Bot. 1975;62:913-922.

75. Rickson FR. Anatomical development of the leaf trichilium and Müllerian bodies of Cecropia peltata L. Am J Bot. 1976;63:1266-1271.

76. Rickson FR. Developmental anatomy and ultrastructure of the ant-food bodies (Beccariian bodies) of Macaranga triloba and M. hypoleuca (Euphorbiaceae). Am J Bot. 1980;67:285-292.

77. O'Dowd DJ. Pearl bodies as ant food: an ecological role for some leaf emergences of tropical plants. Biotropica. 1982;14:40-49.
78. Mayer VE, Frederickson ME, McKey D, Blatrix R. Current issues in the evolutionary ecology of ant-plant symbioses. New Phytol. 2014;202: 749-764.

79. Yamawo A, Hada Y. Effects of light on direct and indirect defences against herbivores of young plants of Mallotus japonicus demonstrate a trade-off between two indirect defence traits. Ann Bot. 2010;106: $143-148$.

80. Rickson FR, Risch SJ. Anatomical and ultrastructural aspects of the ant-food cell of Piper cenocladum C. DC. (Piperaceae). Am J Bot. 1984;71:1268-1274.

81. Rickson FR. Ultrastructural differentiation of the Mullerian body glycogen plastid of Cecropia peltata L. Am J Bot. 1976;63:1272-1279.

82. Janzen DH. Interaction of the bull's-horn acacia (Acacia cornigera) with an ant inhabitant (Pseudomyrmex ferruginea) in eastern Mexico. Kansas Univ Sci Bull. 1967;47:315-558.

83. Heil M, Fiala B, Linsenmair KE, Zotz G, Menke P, Maschwitz U. Food body production in Macaranga triloba (Euphorbiaceae): a plant investment in anti-herbivore defence via symbiotic ant partners. J Ecol. 1997;85:847-861.

84. Orona-Tamayo D, Wielsch N, Blanco-Labra A, Svatos A, FariasRodriguez R, Heil M. Exclusive rewards in mutualisms: ant proteases and plant protease inhibitors create a lock-key system to protect Acacia food bodies from exploitation. Mol Ecol. 2013;22:4087-4100.

85. Heil M, Fiala B, Kaiser W, Linsenmair KE. Chemical contents of Macaranga food bodies: adaptations to their role in ant attraction and nutrition. Funct Ecol. 1998;12:117-122.

86. Fischer RC, Richter A, Wanek W, Mayer V. Plants feed ants: food bodies of myrmecophytic Piper and their significance for the interaction with Pheidole bicornis ants. Oecologia. 2002;133:186-192.

87. Heil M, Baumann B, Kruger R, Linsenmair KE. Main nutrient compounds in food bodies of Mexican Acacia ant-plants. Chemoecology. 2004; 14:45-52.

88. Heckroth HP, Fiala B, Gullan PJ, Idris AH, Maschwitz U. The soft scale (Coccidae) associates of Malaysian ant-plants. J Trop Ecol. 1998;14: $427-443$.

89. Davidson DW, Foster RB, Snelling RR, Lozada PW. Variable composition of some tropical ant-plant symbioses. In: Price PW, Lewinsohn TM, Fernandes GW, Benson WW, editors. Plant-Animal Interactions: Evolutionary Ecology in Tropical and Temperate Regions. New York: Wiley; 1991:145-162.

90. Letourneau DK. Code of ant-plant mutualism broken by parasite. Science. 1990;248:215-217.

91. Linsenmair KE, Heil M, Kaiser WM, Fiala B, Koch T, Boland W. Adaptations to biotic and abiotic stress: Macaranga-ant plants optimize investment in biotic defence. J Exp Bot. 2001;52:2057-2065.

92. Folgarait PJ, Johnson HL, Davidson DW. Responses of Cecropia to experimental removal of Müllerian bodies. Funct Ecol. 1994;8: 22-28.

93. Kautz S, Lumbsch HT, Ward PS, Heil M. How to prevent cheating: a digestive specialization ties mutualistic plant-ants to their ant-plant partners. Evolution. 2009;63:839-853.

94. Jacobs M. On domatia-the viewpoints and some facts. Acad Weten Amsterdam. 1966;69:275-316.

95. Bequaert J. Ants in their diverse relations to the plant world. Bull Am Mus Nat Hist. 1922;45:333-621.

96. Benson WW. Amazon ant plants. In: Prance GT, Lovejoy TE, editors. Amazonia. Oxford: Pergamon Press; 1985:239-266.

97. Fiala B, Maschwitz U. Domatia as most important adaptations in the evolution of myrmecophytes in the paleotropical tree genus Macaranga (Euphorbiaceae). Plant Syst Evol. 1992;180:53-64.

98. Tepe EJ, Vincent MA, Watson LE. Stem diversity, cauline domatia, and the evolution of ant-plant associations in Piper sect. Macrostachys (Piperaceae). Am J Bot. 2007;94:1-11.

99. McKey D. Interaction of the ant-plant Leonardoxa africana (Caesalpiniaceae) with its obligate inhabitants in a rainforest in Cameroon. Biotropica. 1984;16:81-99. 
100. Federle W, Fiala B, Zizka G, Maschwitz U. Incident daylight as orientation cue for hole-boring ants: prostomata in Macaranga ant-plants. Insectes Soc. 2001;48:165-177.

101. Tepe EJ, Kelley WA, Rodriguez-Castaneda G, Dyer LA. Characterizing the cauline domatia of two newly discovered Ecuadorian ant plants in Piper: an example of convergent evolution. J Insect Sci. 2009;9: $1-9$.

102. Bailey IW. Notes on neotropical ant-plants, II. Tachigalia paniculata Aubl. Bot Gaz. 1923;75:27-41.

103. Leroy C, Jauneau A, Quilichini A, Dejean A, Orivel J. Comparison between the anatomical and morphological structure of leaf blades and foliar domatia in the ant-plant Hirtella physophora (Chrysobalanaceae). Ann Bot. 2008;101(4):501-507.

104. Leroy C, Jauneau A, Quilichini A, Dejean A, Orivel J. Comparative structure and ontogeny of the foliar domatia in three neotropical myrmecophytes. Am J Bot. 2010;97:557-565.

105. Gegenbauer C, Mayer VE, Zotz G, Richter A. Uptake of ant-derived nitrogen in the myrmecophytic orchid Caularthron bilamellatum. Ann Bot. 2012;110:757-765.

106. Chanam J, Sheshshayee MS, Kasinathan S, Jagdeesh A, Joshi KA, Borges RM. Nutritional benefits from domatia inhabitants in an antplant interaction: interlopers do pay the rent. Funct Ecol. 2014;28: 1107-1116.

107. Solano PJ, Dejean A. Ant-fed plants: comparison between three geophytic myrmecophytes. Biol J Linn Soc. 2004;83:433-439.

108. Sagers CL, Ginger SM, Evans RD. Carbon and nitrogen isotopes trace nutrient exchange in an ant-plant mutualism. Oecologia. 2000;123: $582-586$.

109. Blüthgen N, Wesenberg J. Ants induce domatia in a rain forest tree (Vochysia vismiaefolia). Biotropica. 2001;33:637-642.

110. Frederickson ME, Ravenscraft A, Miller GA, Hernandez LMA, Booth G, Pierce NE. The direct and ecological costs of an ant-plant symbiosis. Am Nat. 2012;179:768-778.

111. Yu DW, Pierce NE. A castration parasite of an ant-plant mutualism. Proc R Soc Lond B Biol Sci. 1998;265:375-382.

112. Gaume L, Zacharias M, Borges RM. Ant-plant conflicts and a novel case of castration parasitism in a myrmecophyte. Evol Ecol Res. 2005; 7:435-452.

113. Fiala B, Meyer U, bin Hashim R, Maschwitz U. Temporary sterilization behavior of mutualistic partner ants in a Southeast Asian myrmecophyte. Ecol Res. 2014;29:815-822.

114. O'Dowd DJ. Pearl bodies of a neotropical tree, Ochroma pyramidale: ecological implications. Am J Bot. 1980;67:543-549.

115. Rudgers JA, Strauss SY. A selection mosaic in the facultative mutualism between ants and wild cotton. Proc $R$ Soc Lond B Biol Sci. 2004;271:2481-2488.

116. Rutter MT, Rausher MD. Natural selection on extrafloral nectar production in Chamaecrista fasciculata: the costs and benefits of a mutualism trait. Evolution. 2004;58:2657-2668.
117. Radhika V, Kost C, Bartram S, Heil M, Boland W. Testing the optimal defence hypothesis for two indirect defences: extrafloral nectar and volatile organic compounds. Planta. 2008;228:449-457.

118. Millán-Cañongo C, Orona-Tamayo D, Heil M. Phloem sugar flux and jasmonic acid-responsive cell wall invertase control extrafloral nectar secretion in Ricinus communis. J Chem Ecol. 2014;40:760-769.

119. Koricheva J, Romero GQ. You get what you pay for: reward-specific trade-offs among direct and ant-mediated defences in plants. Biol Lett. 2012;8:628-630.

120. Stanton ML, Palmer TM. The high cost of mutualism: effects of four species of East African ant symbionts on their myrmecophyte host tree. Ecology. 2011;92:1073-1082.

121. Romero GQ, Antiqueira PA, Koricheva J. A meta-analysis of predation risk effects on pollinator behaviour. PLoS One. 2011;6:e20689.

122. Rosumek FB, Silveira FAO, Neves FS, et al. Ants on plants: a meta-analysis of the role of ants as plant biotic defenses. Oecologia. 2009;160:537-549.

123. Chamberlain SA, Holland JN. Quantitative synthesis of context dependency in ant-plant protection mutualisms. Ecology. 2009;90: 2384-2392.

124. Sachs JL, Mueller UG, Wilcox TP, Bull JJ. The evolution of cooperation. $Q$ Rev Biol. 2004;79:135-160.

125. Trager MD, Bhotika S, Hostetler JA, et al. Benefits for plants in ant-plant protective mutualisms: a meta-analysis. PLoS One. 2010;5:e14308.

126. Bull JJ, Rice WR. Distinguishing mechanisms for the evolution of cooperation. J Theor Biol. 1991;149:63-74.

127. Fisher BL. Facultative ant association benefits a neotropical orchid. J Trop Ecol. 1992;8:109-114.

128. Trager MD, Bruna EM. Effects of plant age, experimental nutrient addition and ant occupancy on herbivory in a neotropical myrmecophyte. J Ecol. 2006;94:1156-1163.

129. Heil M, Hilpert A, Fiala B, et al. Nutrient allocation of Macaranga triloba ant plants to growth, photosynthesis and indirect defence. Funct Ecol. 2002;16:475-483.

130. Folgarait PJ, Davidson DW. Myrmecophytic Cecropia: antiherbivore defenses under different nutrient treatments. Oecologia. 1995;104: 189-206.

131. Palmer TM, Stanton ML, Young TP, Goheen JR, Pringle RM, Karban R. Putting ant-Acacia mutualisms to the fire. Science. 2008;319: 1760-1761.

132. González-Teuber M, Eilmus S, Muck A, Svatos A, Heil M. Pathogenesis-related proteins protect extrafloral nectar from microbial infestation. Plant J. 2009;58:464-473.

133. Maslin BR, Miller JT, Seigler, DS. Overview of the generic status of Acacia (Leguminosae: Mimosoideae). Australyan Systematic Botany. 2003;16:1-18.

134. Maslin BR. Generic and subgeneric names in Acacia following retypification of the genus. Muelleria. 2008;26:7-9.
Research and Reports in Biodiversity Studies

\section{Publish your work in this journal}

Research and Reports in Biodiversity Studies is an international, peerreviewed, open access journal publishing original research, reports, reviews and commentaries on all areas of biodiversity research. The manuscript management system is completely online and includes a

\section{Dovepress}

very quick and fair peer-review system. Visit http://www.dovepress.com/ testimonials.php to read real quotes from published authors. 